University of Nebraska - Lincoln

DigitalCommons@University of Nebraska - Lincoln

2013

Effect of projectile impact and penetration on the phase composition and microstructure of high performance concretes

\author{
Fei Ren \\ Oak Ridge National Laboratory \\ Catherine H. Mattus \\ Oak Ridge National Laboratory \\ John Jy-An Wang \\ Oak Ridge National Laboratory, wangja@ornl.gov \\ Beverly P. DiPaolo \\ US Army Corps of Engineers
}

Follow this and additional works at: https://digitalcommons.unl.edu/usarmyresearch

Ren, Fei; Mattus, Catherine H.; Wang, John Jy-An; and DiPaolo, Beverly P., "Effect of projectile impact and penetration on the phase composition and microstructure of high performance concretes" (2013). US Army Research. 217.

https://digitalcommons.unl.edu/usarmyresearch/217

This Article is brought to you for free and open access by the U.S. Department of Defense at DigitalCommons@University of Nebraska - Lincoln. It has been accepted for inclusion in US Army Research by an authorized administrator of DigitalCommons@University of Nebraska - Lincoln. 


\title{
Effect of projectile impact and penetration on the phase composition and microstructure of high performance concretes
}

\author{
Fei Ren ${ }^{\mathrm{a}, 1}$, Catherine H. Mattus ${ }^{\mathrm{b}, 1}$, John Jy-An Wang ${ }^{\mathrm{a}, *}$, Beverly P. DiPaolo ${ }^{\mathrm{c}}$ \\ a Materials Science and Technology Division, Oak Ridge National Laboratory, Oak Ridge, TN 37831, United States \\ ${ }^{\mathrm{b}}$ Energy and Transportation Science Division, Oak Ridge National Laboratory, Oak Ridge, TN 37831, United States \\ ${ }^{\mathrm{c}}$ Engineer Research and Development Center, US Army Corps of Engineers, Vicksburg, MS 39180, United States
}

\section{A R T I C L E I N F O}

\section{Article history:}

Received 11 July 2011

Received in revised form 13 April 2013

Accepted 15 April 2013

Available online 24 April 2013

\section{Keywords:}

High performance concrete

Microstructure

SEM

X-ray diffraction

\begin{abstract}
A B S T R A C T
As a result of increased concerns regarding public safety in recent years, the impact and penetration resistance of infrastructure has become an emerging research focus in the cement and concrete industry. Ultra-high performance concretes (UHPCs) with fiber reinforcement usually possess compressive strengths greater than $200 \mathrm{MPa}$ and are promising candidates for penetration-resistant building materials. In the current project, two UHPC materials, ERDC-M (a modified composition developed at U.S. Army Engineer Research and Development Center) and Ductal ${ }^{\circledR}$, were subjected to projectile penetration testing. The microstructural evolution due to projectile impact and penetration was examined via scanning electron microscopy and X-ray diffraction. Possible phase changes were observed in the affected material volume, which can be interpreted as resulting from the high temperature and high pressure induced by the impact and penetration.
\end{abstract}

(c) 2013 Elsevier Ltd. All rights reserved.

\section{Introduction}

As a result of increased concerns regarding public safety in recent years, the resistance of infrastructure to impact and penetration has become an emerging research focus in the cement and concrete industry [1,2]. Improvements in concrete mix design and material processing, along with the addition of metallic fibers, have led to a new high-performance cement material known as ultra-high performance concrete/reactive powder concrete (UHPC/ RPC) with quasi-static unconfined compressive strengths typically above $200 \mathrm{MPa}$ after post-set heat treatment [3-5]. UHPC/RPC has a composition quite similar to that of normal concrete. The optimization of UHPC/RPC performance is achieved by improvements in the homogeneity and the compactness of the mix. The more homogeneous material is obtained by reducing the particle size and optimizing the flow properties of the fresh concrete, whereas the compactness is influenced by optimization of the granular mix,

Abbreviations: $\mathrm{C}_{2} \mathrm{~S}, 2 \mathrm{CaO} \cdot \mathrm{SiO}_{2} ; \mathrm{C}_{3} \mathrm{~A}, 3 \mathrm{CaO} \cdot \mathrm{Al}_{2} \mathrm{O}_{3} ; \mathrm{C}_{3} \mathrm{~S}, 3 \mathrm{CaO} \cdot \mathrm{SiO}_{2} ; \mathrm{C}_{4} \mathrm{AF}, 4 \mathrm{CaO} \cdot \mathrm{Al}_{2}$ $\mathrm{O}_{3} \cdot \mathrm{Fe}_{2} \mathrm{O}_{3} ; \mathrm{C}-\mathrm{S}-\mathrm{H}$, calcium silicate hydrates; ERDC, Engineer Research and Development Center; mm, millimeter (one thousandth of a meter); $\mathrm{MPa}$, megapascal; $\mathrm{m} / \mathrm{s}$, meter/second; RPC, reactive powder concrete; SEM, scanning electron microscope; STAR, Shock Thermodynamic Applied Research; TBF, terminal ballistic facility; UHPC, ultra high performance concrete; XRD, X-ray diffraction.

* Corresponding author. Tel.: +1 8655742274.

E-mail address: wangja@ornl.gov (J.Jy-An Wang).

1 These authors equally contributed to this work. the water/cement ratio, and the use of ultra-fine pozzolans and superplasticizers [6,7]. The reduction of the pore sizes in the microstructure obtained through these methods leads to a higher compression resistance and lower permeability. The addition of metallic fibers to the granular mix increases the tensile strength and improves the crack resistance. Heat treatment can produce additional improvement in the quality of the microstructure $[3,5,8-11]$.

UHPC/RPC materials have unique advantages with respect to mechanical properties, environmental stability, construction methods, structural designs, and aesthetic qualities. Furthermore, research on protective structures has indicated that UHPC/RPC materials can significantly improve resistance to penetration from high-velocity fragments and projectiles compared with conventional construction using normal-strength concretes [2,12-15]. Thus UHPC/RPC has great potential for the construction of infrastructures offering more resistance to attacks involving high velocity projectiles.

On the other hand, high speed impact may generate high temperature that could lead to dehydroxylation and decomposition in many cementitious phases. Development of various gaseous phases may result in pressure built-up, which could in turn damage the structural integrity of high performance concretes, and especially UHPCs due to their extremely low porosities. Therefore, it is of great interest to study the microstructure and phase composition of UHPCs subject projectile impact and penetration. 
Table 1

Material formulations for the two UHPCs included in this study.

\begin{tabular}{|c|c|c|c|c|}
\hline Constituents & ERDC-M & $\begin{array}{l}\text { Weight ratio with respect to } \\
\text { cement }\end{array}$ & Ductal $^{\circledR}$ & $\begin{array}{l}\text { Weight ratio with respect to } \\
\text { cement }\end{array}$ \\
\hline Cement & Class $\mathrm{H}^{\mathrm{a}}$ & 1.00 & Portland $^{\mathrm{b}}$ & 1.00 \\
\hline \multirow[t]{3}{*}{ Aggregate } & Sand $(-600 \mu \mathrm{m})$ & 0.97 & Sand $(-600 \mu \mathrm{m})$ & 1.43 \\
\hline & Silica fume & 0.39 & Silica fume & 0.32 \\
\hline & Silica flour & 0.28 & Silica flour & 0.30 \\
\hline Water & & 0.21 & & 0.20 \\
\hline HRWRA $^{c}$ & & 0.01 & & 0.02 \\
\hline Fiber & $\begin{array}{l}\text { Bekaert Dramix }{ }^{\circledR} \text { ZP305-steel, } \\
l=30 \mathrm{~mm}, l / d=55\end{array}$ & 0.31 & $\begin{array}{l}\text { Baumbach Metall GmbH-steel, } \\
l=14 \mathrm{~mm}, l / d=76\end{array}$ & 0.22 \\
\hline
\end{tabular}

\footnotetext{
a Mixture based on [22].

b Mixture similar to [23].

c HRWRA-high-range water-reducing agent.
}

This research used two UHPC materials, ERDC-M (a modified composition developed at U.S. Army Engineer Research and Development Center) and Ductal ${ }^{\circledR}$, for a projectile impact and penetration resistance study. Microstructures and phase information were collected from tested concrete slabs through the use of scanning electron microscopy (SEM) and X-ray diffraction (XRD) and were analyzed and compared with similarly collected data obtained from control samples that were not subject to impact testing. The microstructural changes observed in the test materials can be interpreted as resulting from the temperature and pressure environments induced by the impact and penetration processes.

\section{Materials and methods}

Two concrete formulations were examined in this study: UHPC fabricated from ERDC-M developed by the U.S. Army Engineer Research and Development Center (ERDC) [15] and from commercial Ductal $^{\circledR}$ premix (Ductal ${ }^{\circledR}$ BS1000.0308 Grey, Lafarge North America, USA). The compositions for both formulations are given in Table 1 . The ERDC-M was obtained by curing the mixture (Table 1) for seven days in a fog room followed by four days in hot water $\left(90^{\circ} \mathrm{C}\right)$ and two days in an oven $\left(90^{\circ} \mathrm{C}\right)$. The Ductal ${ }^{\circledR}$ concrete samples were fabricated by curing the mixture (Table 1 ) for one day in

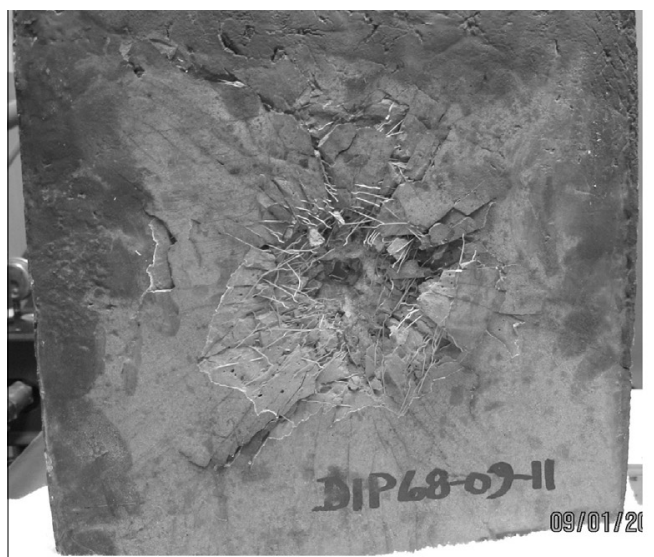

(a)

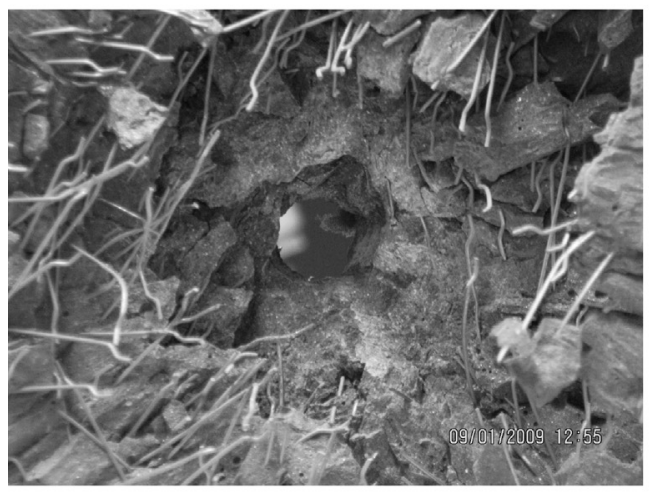

(c)

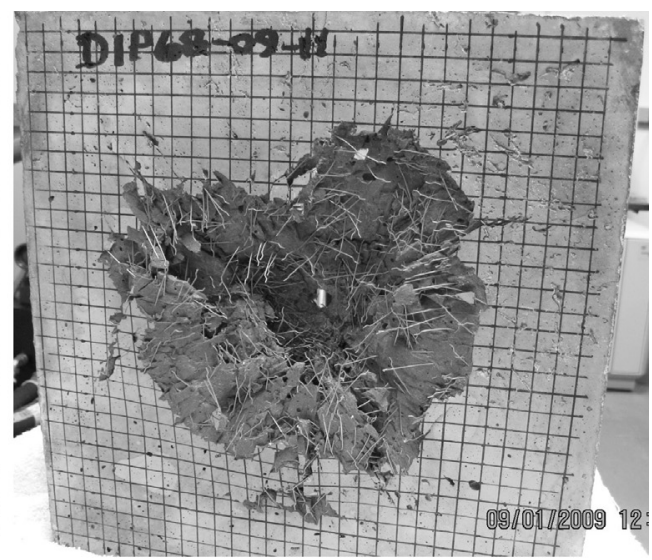

(b)

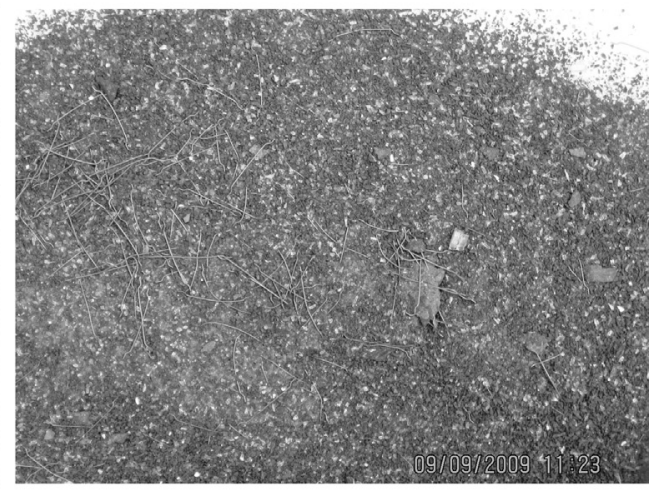

(d)

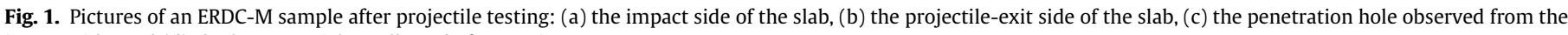
impact side, and (d) the loose particles collected after testing. 
a fog room and two days in hot water $\left(90^{\circ} \mathrm{C}\right)$. The total free water porosity, as calculated from the masses of identical samples first saturated and then dried in a vacuum oven, was $1.94 \%$ for the ERDC-M and $2.25 \%$ for the Ductal ${ }^{\circledR}$. The quasi-static unconfined compressive strengths were approximately 211 and $185 \mathrm{MPa}$, respectively.

For projectile penetration testing, ERDC-M and Ductal ${ }^{\circledR}$ slabs with dimensions of $\sim 304 \times 304 \times 76 \mathrm{~mm}$ were prepared at ERDC. With the $304 \times 304 \mathrm{~mm}$ surfaces designated as the target impact surfaces (Fig. 1a and b), ballistic impact experiments were performed at the Sandia National Laboratories Shock Thermodynamic Applied Research (STAR) facility on the terminal ballistic facility (TBF) gun system. For the tests, the TBF gun was configured as a single stage powder gun with 50 caliber bore. The barrel uses standard military rifling with one turn in $381 \mathrm{~mm}$ and a length of $1.83 \mathrm{~m}$ and fires into a flight range that is evacuated to a nominal 1 torr ( $\sim 133 \mathrm{~Pa})$ absolute pressure. The projectile used was a 0.50 caliber, Ball, M33 boat-tailed bullet with a full copper alloy jacket over a steel core and the nominal impact speed of this bullet is around $914 \mathrm{~m} / \mathrm{s}$ [15]. Experimental data included projectile impact velocity and post-penetration residual velocity from electronic and radiographic techniques and high-speed photography of the projectile prior to impact, at impact, and at exit from the test specimens. Further details and the data form the penetration testing are given in Ref. [16]. The specimens were then used to study changes in the materials due to projectile impact and penetration.

Following penetration testing, samples were collected from the concrete slabs and examined using XRD (X'Pert Pro, PANalytical, the Netherlands) and SEM (XL30, Phillips, the Netherlands). Each sample was ground with mortar and pestle and passed through a $53-\mu \mathrm{m}$ sieve prior to XRD. No mineralogical changes in the ground powder were expected from the manual grinding process. SEM samples were collected from both the bulk concrete slabs (Fig. 1c) and the fragmented concrete pieces (Fig. 1d). All SEM samples were coated with carbon to make the samples sufficiently conductive for SEM observation. For comparison, control samples (not subjected to penetration testing) of both ERDC-M and Ductal ${ }^{\circledR}$ were also investigated using similar XRD and SEM techniques.

\section{Results and discussion}

\subsection{Control samples: unloaded UHPC}

The results on SEM microstructure examination and XRD phase analysis of UHPC materials are presented in this section.

\subsubsection{SEM observation}

For both ERDC-M and Ductal ${ }^{\circledR}$, fracture surfaces were examined under SEM. The ERDC-M material possessed a typical microstructure/morphology that can be observed on a normal cement paste, except for a significant fraction of unreacted/anhydrous $3 \mathrm{CaO} \cdot \mathrm{SiO}_{2}$ $\left(\mathrm{C}_{3} \mathrm{~S}\right)$ surrounded by distinct calcium silicate hydrate $(\mathrm{C}-\mathrm{S}-\mathrm{H})$ crowns (Fig. 2a). Good bonding between the quartz grains and the cement paste was observed (Fig. 2b). Transgranular fractures observed through the quartz grains (Fig. 2c) also suggested that the interfacial bonding had a superior strength. The $\mathrm{C}-\mathrm{S}-\mathrm{H}$ in the paste appeared dense, although a few micropores were visible (Fig. 2a and b). In addition, reacted silica fume particles were observed (Fig. 2d). However, the bond between the cement paste and the Dramix ${ }^{\circledR}$ fibers was not very good, as evidenced by the smooth and paste-free fiber surfaces.

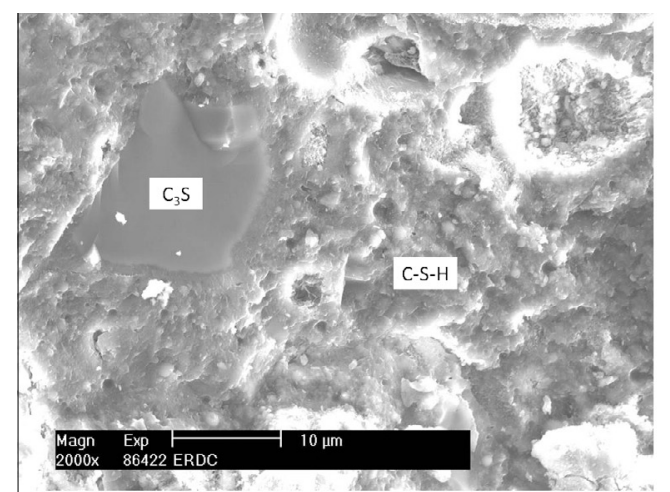

(a)

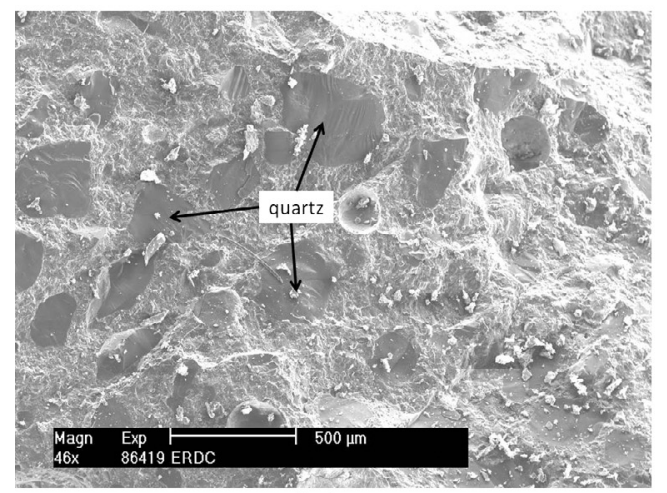

(c)

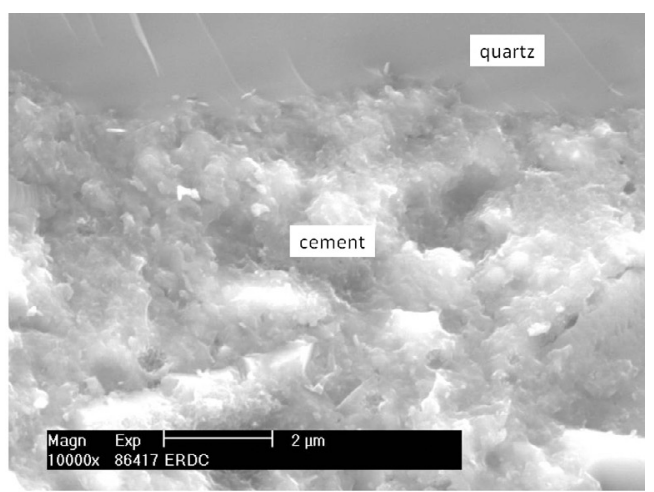

(b)

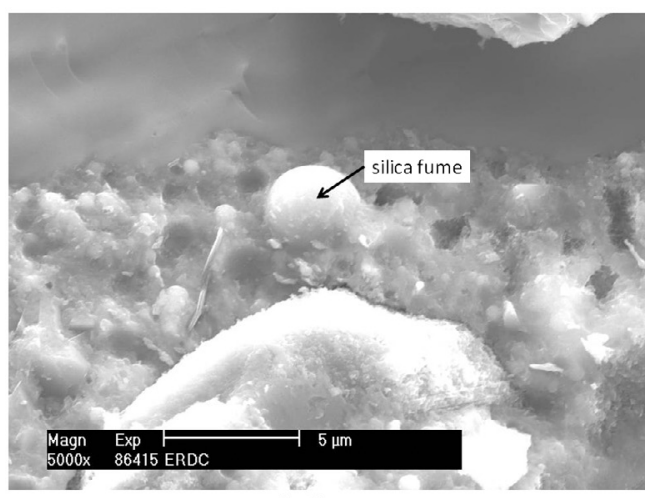

(d)

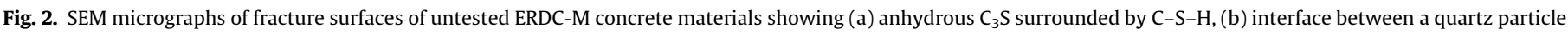
and the cement paste, (c) transgranular fractures through the quartz grains, and (d) reacted silica fume particles. 


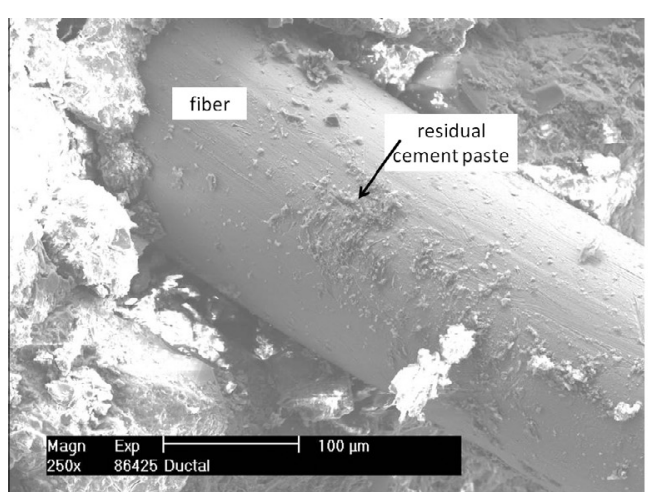

(a)

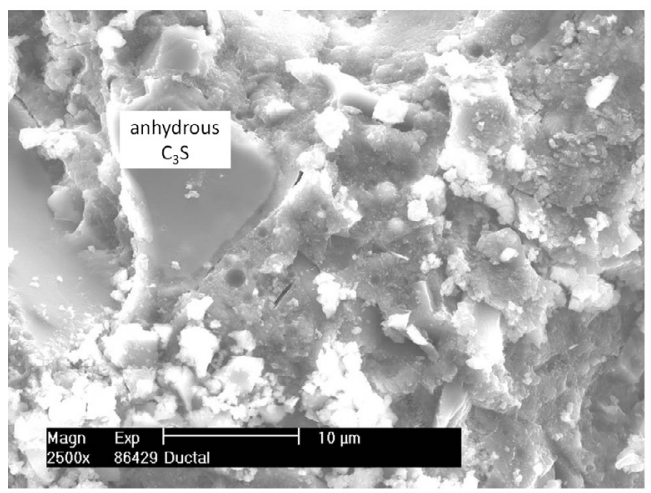

(c)

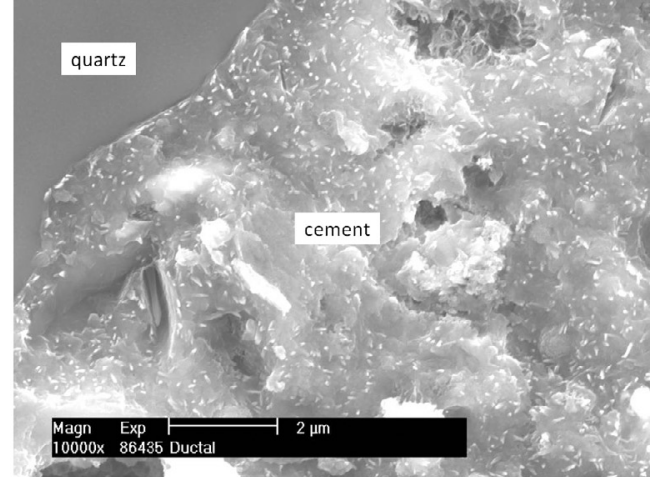

(b)

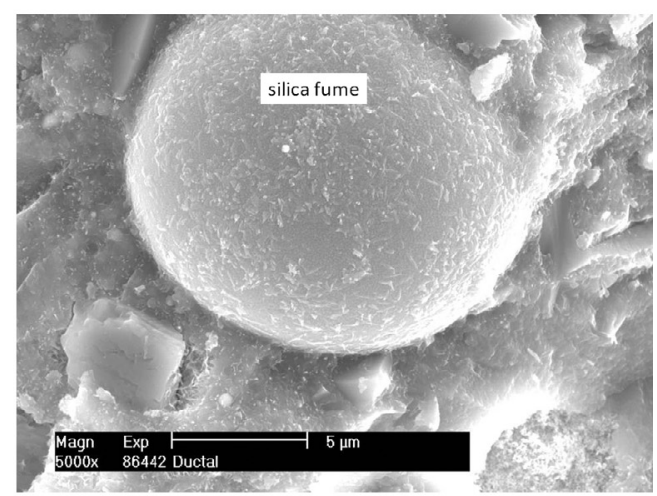

(d)

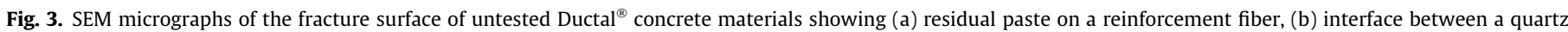
particle and the cement paste, (c) anhydrous phases in the paste, and (d) a silica fume particle embedded in the cement.

In contrast, the Ductal ${ }^{\circledR}$ concrete exhibited good adherence between the cement paste and the Baumbach reinforcement fibers (Fig. 3a) and good bonding without cracks or gaps between the paste and the quartz particles (Fig. $3 \mathrm{~b}$ ). The cement paste between the quartz particles and the remaining anhydrous clinker was very dense (Fig. 3b). A much higher amount of anhydrous clinker remained in the paste than in a normal concrete (Fig. 3c), and some reacted silica fume particles were observed (Fig. 3d).

\subsubsection{XRD analysis}

Fig. 4 shows the XRD profiles for both the untested ERDC-M and untested Ductal ${ }^{\circledR}$ materials. Although it is difficult to quantitatively analyze the XRD results because of the complexity of the profiles (Fig. 4), a semi-quantitative or qualitative analysis using a commercial software package (X'Pert HighScore ${ }^{\circledR}$, PANalytical, the Netherlands) was performed in terms of the probability that a phase may be present in the samples. The XRD results are summarized and tabulated in Tables 2a,b.

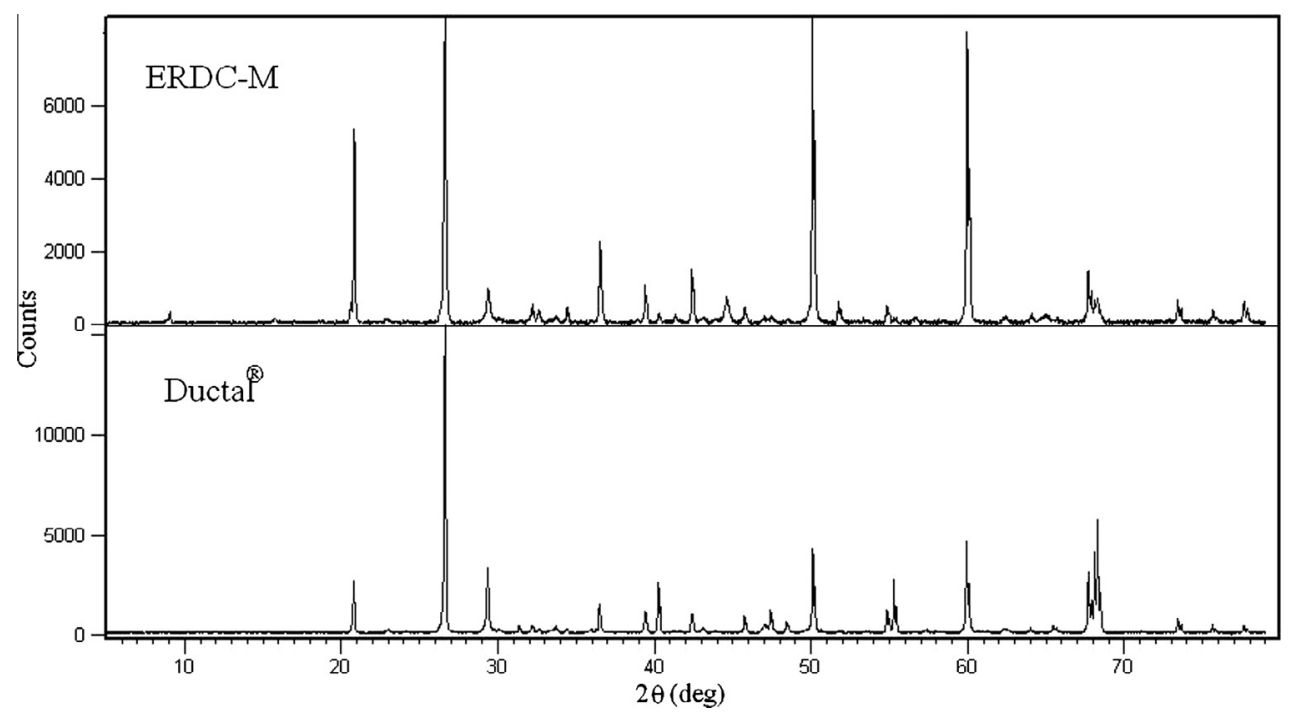

Fig. 4. XRD profiles of the untested ERDC-M and Ductal ${ }^{\circledR}$ materials. 
Both concretes contain quartz and typical residues from anhydrous clinkers $-C_{3} S$ or alite, $C_{2} S$ or belite, $C_{4} A F$ (alumino ferritic phase) or brownmillerite, and $C_{3} A$ possibly with substitutions such as in grossular $\mathrm{Ca}_{3} \mathrm{Al}_{2}\left(\mathrm{SiO}_{4}\right)_{3}$ (Tables 2a,b). In addition, both materials contain some $\mathrm{C}-\mathrm{S}-\mathrm{H}\left(\mathrm{Ca}_{1.5} \mathrm{SiO}_{3.5} \cdot \mathrm{xH}_{2} \mathrm{O}\right)$, probably a tobermorite $\left(9 \AA \quad\right.$ riversideite $\left.\quad \mathrm{Ca}_{5} \mathrm{Si}_{6} \mathrm{O}_{16}(\mathrm{OH})_{2}\right)$, and/or $\mathrm{Ca}_{2.25}\left(\mathrm{Si}_{3} \mathrm{O}_{7.5}(\mathrm{OH})_{1.5}\right)\left(\mathrm{H}_{2} \mathrm{O}\right)$, and a form of vesuvianite (possibly $\mathrm{Al}_{11.8} \mathrm{Ca}_{19} \mathrm{Fe}_{1.2} \mathrm{H}_{8.2} \mathrm{O}_{78} \mathrm{Si}_{18}$ ) (Table 2a,b). The difference observed between the two UHPC concretes resides mainly in the nature of the hydrates. For example, the ERDC-M probably contains ettringite, $\left(\mathrm{Ca}_{6} \mathrm{Al}_{2}\left(\mathrm{SO}_{4}\right)_{3}(\mathrm{OH})_{12} \cdot 26 \mathrm{H}_{2} \mathrm{O}\right)$ (Table $2 \mathrm{a}$ ), whereas the Ductal ${ }^{\circledR}$ material does not (Table $2 \mathrm{~b}$ ).

\subsection{UHPC after impact testing}

After impact testing, the microstructure and phases of the UHPC materials were also investigated via SEM and XRD.

\subsubsection{SEM observation}

Fig. 5 shows representative SEM images obtained from the ERDC-M materials after impact and penetration testing. The fracture surfaces were covered with small bright silica particles
(Fig. 5a). A reversible phase transformation between $\alpha$-quartz and $\beta$-quartz takes place at $573^{\circ} \mathrm{C}$ with a large volume change [17]. The temperature reached in the concrete in the impact zone was likely much higher than $573{ }^{\circ} \mathrm{C}$. Thus, the small silica particles could have been created by the phase transformation of quartz near the impact zone.

In contrast, in a region further away from the impact zone, the microstructure of the fracture surface resembled that of the untested concrete. The contact of the cement paste with the quartz aggregates was very good (Fig. $5 \mathrm{~b}$ ), and $\mathrm{C}_{3} \mathrm{~S}$ grains were found to be surrounded by $\mathrm{C}-\mathrm{S}-\mathrm{H}$ layers (Fig. $5 \mathrm{c}$ ). In some regions $\mathrm{Ca}(\mathrm{OH})_{2}$ crystals were also observed (Fig. $5 \mathrm{~d}$ ).

Similarly, silica particles were found on the fracture surfaces of tested Ductal ${ }^{\circledR}$ samples (Fig. 6a). Residual cement paste was observed on metal fibers, indicating a good bonding between the paste and the fibers (Fig. $6 \mathrm{~b}$ ). In some areas, $\mathrm{C}_{3} \mathrm{~S}$ crystals appeared to have recrystallized (Fig. $6 \mathrm{c}$ ). This could happen if the cooling rate after impact was slow instead of the rapid quench that clinker usually receives. Some hydrates rich in silica are locally visible in this sample. In addition, some $\mathrm{Mg}(\mathrm{OH})_{2}$ crystals were observed (Fig. 6d) , which could be a result of the high temperature during impact and the hydration in the following cooling period.

Table 2a

Possible phases in the untested and tested ERDC-M concrete materials.

\begin{tabular}{|c|c|c|c|c|}
\hline Mineral phase & Chemical formula & As-fabricated & Region near the impact zone & Loose particles \\
\hline Quartz low & $\mathrm{SiO}_{2}$ & 80 & 78 & 82 \\
\hline Coesite & $\mathrm{SiO}_{2}$ & ni & ni & 46 \\
\hline Alite & $\mathrm{Ca}_{3} \mathrm{SiO}_{5}$ & 55 & 88 & 85 \\
\hline Belite & $\mathrm{Ca}_{2}\left(\mathrm{SiO}_{4}\right)$ & 26 & ni & ni \\
\hline Larnite & $\mathrm{Ca}_{2}\left(\mathrm{SiO}_{4}\right)$ & ni & 36 & 33 \\
\hline Vesuvianite & $\mathrm{Ca}_{10} \mathrm{Mg}_{2} \mathrm{Al}\left(\mathrm{SiO}_{4}\right)_{5}\left(\mathrm{Si}_{2} \mathrm{O}_{7}\right)(\mathrm{OH})_{4}$ & 21 & 47 & 42 \\
\hline Brownmillerite & $\mathrm{CaAl}_{1.1} \mathrm{Fe}^{2+}{ }_{0.9} \mathrm{O}_{5}$ & ni & 47 & 34 \\
\hline Grossular & $\mathrm{Ca}_{3} \mathrm{Al}_{2}\left(\mathrm{SiO}_{4}\right)_{5}$ & ni & ni & 34 \\
\hline Portlandite & $\mathrm{Ca}(\mathrm{OH})_{2}$ & 31 & ni & ni \\
\hline Ettringite & $\mathrm{Ca}_{6} \mathrm{Al}_{2}\left(\mathrm{SO}_{4}\right)_{3}(\mathrm{OH})_{12} \cdot 26\left(\mathrm{H}_{2} \mathrm{O}\right)$ & 26 & ni & ni \\
\hline Tobermorite $9 \AA$ & $\mathrm{Ca}_{5} \mathrm{Si}_{6} \mathrm{O}_{16}(\mathrm{OH})_{2}$ & 25 & 36 & ni \\
\hline Clinotobermorite & $\mathrm{Ca}_{5} \mathrm{Si}_{6} \mathrm{O}_{14}(\mathrm{OH})_{4} \cdot 5\left(\mathrm{H}_{2} \mathrm{O}\right)$ & ni & ni & 22 \\
\hline Rosenhahnite & $\mathrm{Ca}_{3} \mathrm{Si}_{3} \mathrm{O}_{8}(\mathrm{OH})_{2}$ & 22 & 34 & ni \\
\hline Calcite & $\mathrm{CaCO}_{3}$ & 34 & 33 & ni \\
\hline Spinel & $\mathrm{MgAl}_{2} \mathrm{O}_{4}$ & 30 & ni & ni \\
\hline Gismondine & $\mathrm{Ca}_{2} \mathrm{Al}_{4} \mathrm{Si}_{4} \mathrm{O}_{16} \cdot 9\left(\mathrm{H}_{2} \mathrm{O}\right)$ & ni & 29 & ni \\
\hline Hibschite & $\mathrm{Ca}_{3} \mathrm{Al}_{2}\left(\mathrm{SiO}_{4}\right)_{2}(\mathrm{OH})_{4}$ & ni & 29 & ni \\
\hline Foshagite & $\mathrm{Ca}_{4}\left(\mathrm{Si}_{3} \mathrm{O}_{9}\right)(\mathrm{OH})_{2}$ & ni & 31 & ni \\
\hline Unnamed zeolite & $\mathrm{M}_{2 / \mathrm{n}} \mathrm{O} \cdot \mathrm{Al}_{2} \mathrm{O}_{3} \cdot \mathrm{xSiO}_{2} \cdot \mathrm{yH}_{2} \mathrm{O}$ & ni & 37 & ni \\
\hline
\end{tabular}

ni: Not identified. The numbers correspond to the probability (in \%) that the phase is present in the sample.

Table 2b

Possible phases in the untested and tested Ductal ${ }^{\circledR}$ concrete materials.

\begin{tabular}{|c|c|c|c|c|}
\hline Mineral phase & Chemical formula & As-fabricated & Region near the impact zone & Brown material \\
\hline Quartz low & $\mathrm{SiO}_{2}$ & 84 & 84 & 81 \\
\hline Coesite & $\mathrm{SiO}_{2}$ & ni & ni & 55 \\
\hline Cristobalite & $\mathrm{SiO}_{2}$ & ni & 40 & ni \\
\hline Alite & $3 \mathrm{CaO} \cdot \mathrm{SiO}_{2}$ & 51 & 89 & 89 \\
\hline Belite & $2 \mathrm{CaO} \cdot \mathrm{SiO}_{2}$ & 26 & 46 & 45 \\
\hline Vesuvianite & $\mathrm{Ca}_{10} \mathrm{Mg}_{2} \mathrm{Al}_{4}\left(\mathrm{SiO}_{4}\right)_{5}\left(\mathrm{Si}_{2} \mathrm{O}_{7}\right)_{2}(\mathrm{OH})_{4}$ & ni & 52 & 51 \\
\hline Brownmillerite & $\mathrm{Ca}_{2} \mathrm{Al}_{1.1} \mathrm{Fe}^{2+}{ }_{0.9} \mathrm{O}_{5}$ & 31 & 48 & 44 \\
\hline Portlandite & $\mathrm{Ca}(\mathrm{OH})_{2}$ & 32 & ni & ni \\
\hline Tobermorite $9 \AA$ & $\mathrm{Ca}_{5} \mathrm{Si}_{6} \mathrm{O}_{16}(\mathrm{OH})_{2}$ & 25 & ni & ni \\
\hline Clinotobermorite & $\mathrm{Ca}_{5} \mathrm{Si}_{6} \mathrm{O}_{14}(\mathrm{OH})_{4} \cdot 5\left(\mathrm{H}_{2} \mathrm{O}\right)$ & ni & 32 & 30 \\
\hline Calcite & $\mathrm{CaCO}_{3}$ & ni & 51 & 44 \\
\hline Spinel & $\mathrm{MgAl}_{2} \mathrm{O}_{4}$ & ni & 46 & 44 \\
\hline Scawtite & $\mathrm{Ca}_{7} \mathrm{Si}_{6}\left(\mathrm{CO}_{3}\right) \mathrm{O}_{18} \cdot 2\left(\mathrm{H}_{2} \mathrm{O}\right)$ & 24 & ni & ni \\
\hline Merwinite & $\mathrm{Ca}_{3}(\mathrm{Mg})\left(\mathrm{SiO}_{4}\right)_{2}$ & ni & 45 & 44 \\
\hline Wollastonite & $\mathrm{Ca}_{0.949} \mathrm{Mg}_{0.01} \mathrm{Fe}_{0.036} \mathrm{SiO}_{3}$ & ni & 34 & 32 \\
\hline Periclase & $\mathrm{MgO}$ & ni & ni & 44 \\
\hline Calcium magnesium aluminum silicate & $\mathrm{Ca}_{54} \mathrm{MgAl}_{2} \mathrm{Si}_{16} \mathrm{O}_{90}$ & ni & 82 & 79 \\
\hline
\end{tabular}

ni: Not identified. The numbers correspond to the probability in (\%) that the phase is in the sample. 


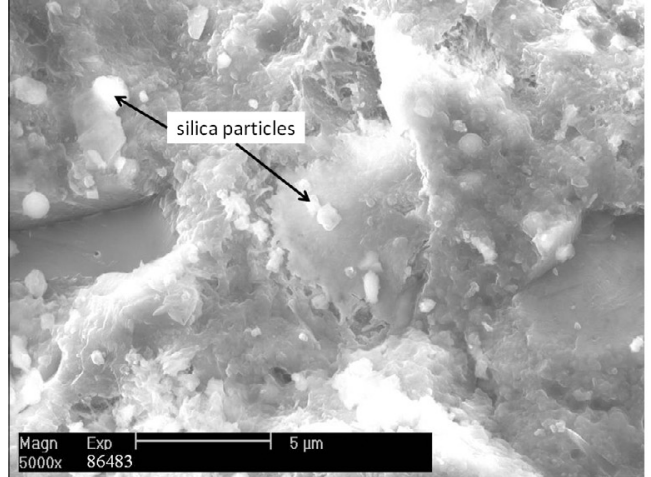

(a)

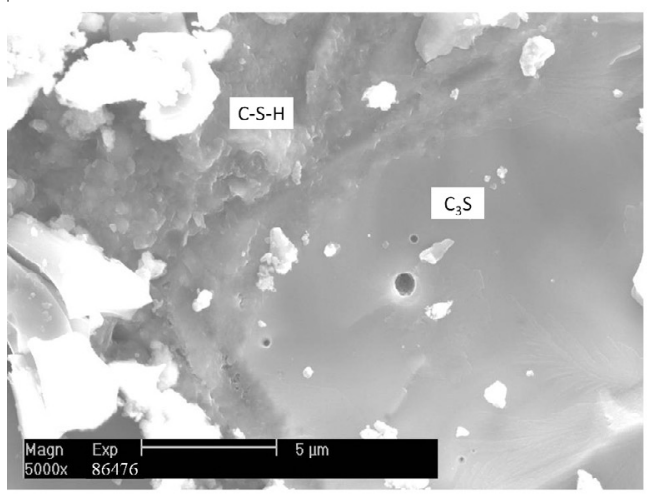

(c)

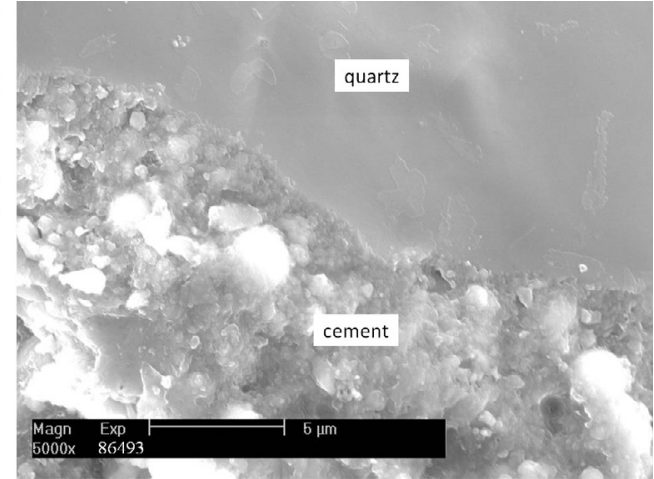

(b)

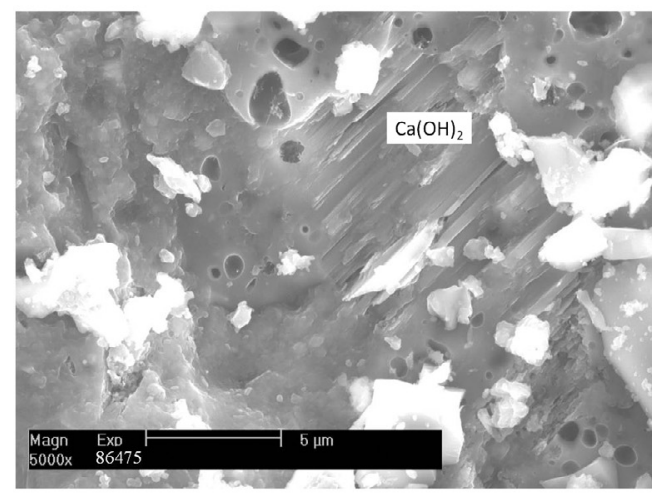

(d)

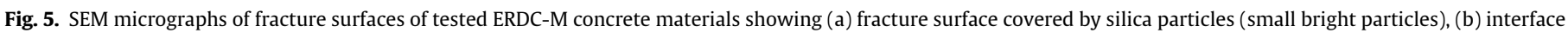
between quartz particle and the cement paste, (c) $\mathrm{C}_{3} \mathrm{~S}$ grains surrounded by $\mathrm{C}-\mathrm{S}-\mathrm{H}$ layers, and (d) $\mathrm{Ca}(\mathrm{OH})_{2} \mathrm{crystals}$.

Compared with the untested material (Figs. 2 and 3), the tested

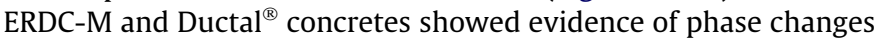
(Figs. $5 \mathrm{a}$ and $6 \mathrm{a}, \mathrm{c}, \mathrm{d}$ ). These phase changes were likely a result of the high temperature and high pressure induced by the projectile impact. During the impact, the concretes were subjected not only to the stress associated with the mechanical impact from the bullet but also to that from chemical transformations occurring in the paste as a result of the elevated temperatures. The high temperature reached in the area of impact could create gaseous phases such as water vapor resulting from the decomposition of hydrates. These gases are trapped in the material, resulting in a pressure increase in the local vicinity.

\subsubsection{XRD analysis}

For the ERDC-M material, XRD was performed on powders collected from both the bulk volume around the impact zone and the broken pieces and loose particles derived from the impact (Table $2 \mathrm{a})$. The anhydrous residues of $\mathrm{C}_{3} \mathrm{~S}\left(\mathrm{Ca}_{3} \mathrm{SiO}_{5}\right.$ or alite) were found in both tested samples and untested ERDC-M. However, different phases of $\mathrm{C}_{2} \mathrm{~S}$ were observed: the belite phase was observed in the untested sample, whereas larnite was found in the two tested samples. As expected, low quartz was found in all three samples, but a high-temperature, high-pressure phase of silica, coesite [18], was also identified in the loose particles.

The hydrate phases of portlandite and ettringite present in the untested ERDC-M were absent in the tested samples (Table 2a). This finding indicates that the temperature experienced by the samples at or near the impact zone was likely higher than $\sim 550^{\circ} \mathrm{C}$, the temperature required to initiate the dehydroxylation of portlandite. Tobermorite $9 \AA$ A was identified in the untested concrete and in the sample collected near the impact zone. In contrast, clinotobermorite was observed in the loose particles (Table 2a). The differences between the two tested samples may result from the different temperature increases at different locations in the concrete slab. Since it was further away from the impact center, it was likely that the material collected around the impact zone experienced a lower temperature during testing than the loose particles, which were probably ejected from the impact center.

For the tested Ductal ${ }^{\circledR}$ material, powders were also collected from the bulk material near the impact zone. In addition, small amounts of brownish particles were found and collected from the central region of impact. The brown particles were very easy to break up, implying a low cohesion of the material.

Table $2 \mathrm{~b}$ lists the mineralogical phases identified for the Ductal $^{\circledR}$ samples. Comparison of the tested and untested specimens results in conclusions very similar to those reached for the ERDC-M concrete: (1) the alite and brownmillerite phases are found to be unchanged between the untested and tested specimens; (2) the quartz present in the untested specimen was transformed to a phase such as coesite; (3) the hydrates present in the untested Ductal ${ }^{\circledR}$ concrete - such as portlandite $\left(\mathrm{Ca}(\mathrm{OH})_{2}\right)$ and tobermorite $\left(\mathrm{Ca}_{5} \mathrm{Si}_{6} \mathrm{O}_{16}(\mathrm{OH})_{2}\right)$ and possibly scawtite $\left(\mathrm{Ca}_{7} \mathrm{Si}_{6}\left(\mathrm{CO}_{3}\right) \mathrm{O}_{18} \cdot 2 \mathrm{H}_{2} \mathrm{O}\right)-$ were not seen in the tested specimens; (4) new hydrates - vesuvianite $\left(\mathrm{Ca}_{10} \mathrm{Mg}_{2} \mathrm{Al}_{4}\left(\mathrm{SiO}_{4}\right)_{5}\left(\mathrm{Si}_{2} \mathrm{O}_{7}\right)_{2}(\mathrm{OH})_{4}\right)$ and clinotobermorite $\left(\mathrm{Ca}_{5}\right.$ $\mathrm{Si}_{6} \mathrm{O}_{14}(\mathrm{OH})_{4} \cdot 5\left(\mathrm{H}_{2} \mathrm{O}\right)$. New anhydrous minerals - calcite $\left(\mathrm{CaCO}_{3}\right)$, spinel $\left(\mathrm{MgAl}_{2} \mathrm{O}_{4}\right)$, and merwinite $\left(\mathrm{Ca}_{3}(\mathrm{Mg})\left(\mathrm{SiO}_{4}\right)_{2}\right.$ - were observed in the tested Ductal ${ }^{\circledR}$ samples, but were absent in the tested ERDC$\mathrm{M}$ samples. This difference could be a result of the selection of specimens for analysis and/or the impurity in the materials selected for the formulation.

A possible explanation for the changes in the tested materials is that during testing the temperature in the impact vicinity 


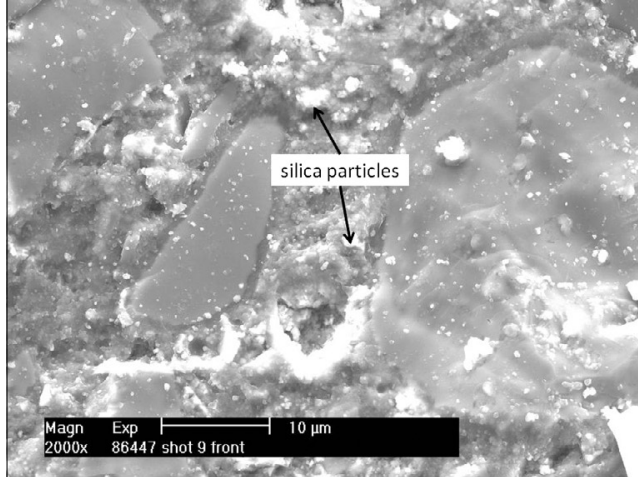

(a)

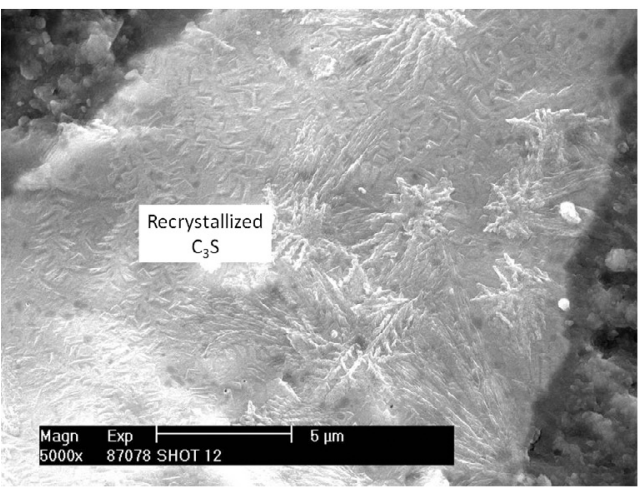

(c)

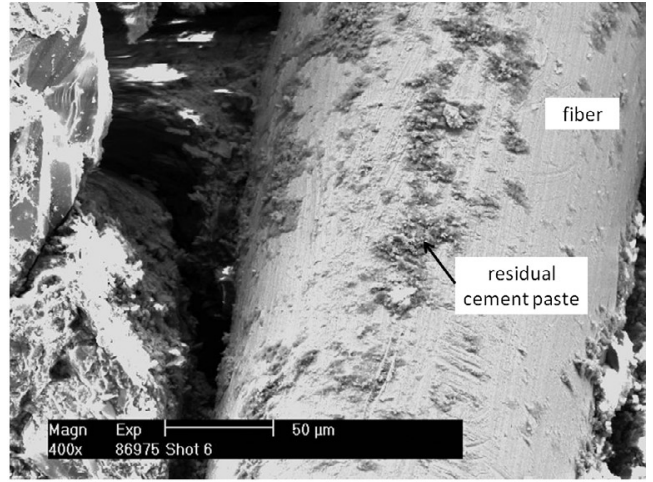

(b)

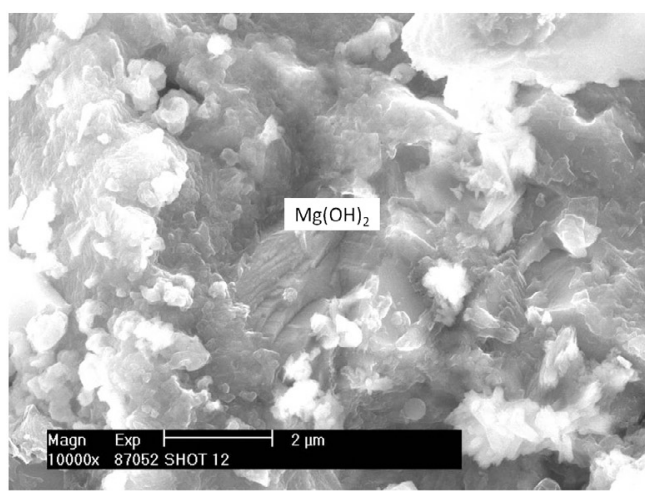

(d)

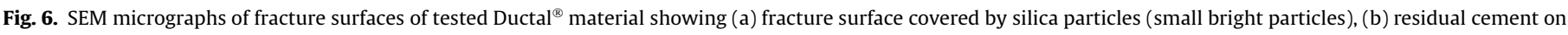
a reinforcement fiber, (c) recrystallized $\mathrm{C}_{3} \mathrm{~S}$, and $(\mathrm{d}) \mathrm{Mg}(\mathrm{OH})_{2}$ crystals that were likely formed during the impact testing.

increased significantly, causing the concrete to lose water. The hydrates ultimately formed anhydrous oxides, including $\mathrm{CaO}, \mathrm{SiO}_{2}$, $\mathrm{Al}_{2} \mathrm{O}_{3}$, and $\mathrm{MgO}$. Some oxides, such as $\mathrm{CaO}$ and $\mathrm{MgO}$, are very reactive with water. During the cooling period, these oxides could have been hydrolyzed or carbonated if humidity or $\mathrm{CO}_{2}$ were present. Similarly, other hydrates such as tobermorite lost water and, upon cooling, captured water and formed new hydrates such as clinotobermorite. Possible transformation processes of portlandite $\left(\mathrm{Ca}(\mathrm{OH})_{2}\right)$ and tobermorite $\left(\mathrm{Ca}_{5} \mathrm{Si}_{6} \mathrm{O}_{16}(\mathrm{OH})_{2}\right)$ upon heating and during cooling are given as examples in Eqs. (1) and (2):

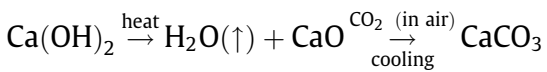

$\mathrm{Ca}_{5} \mathrm{Si}_{6} \mathrm{O}_{16}(\mathrm{OH})_{2} \stackrel{\text { heat }}{\rightarrow} 5 \mathrm{CaO} \cdot 6 \mathrm{SiO}_{2} \cdot \mathrm{H}_{2} \mathrm{O}(\uparrow) \underset{\text { cooling }}{\text { moisture }} \mathrm{Ca}_{5} \mathrm{Si}_{6} \mathrm{O}_{14}(\mathrm{OH})_{4} \cdot 5 \mathrm{H}_{2} \mathrm{O}$

During the heating period, the evaporation of water could have generated internal stress, and the escape of the water vapor could have provoked spalling. On the other hand, during the cooling period, the oxides formed could have captured water to form new hy drated phases. There is also a possibility of dimensional change as $\mathrm{CaO}$ and $\mathrm{MgO}$ hydrate to form $\mathrm{Ca}(\mathrm{OH})_{2}$ and $\mathrm{Mg}(\mathrm{OH})_{2}$.

As mentioned earlier (Section 3.2.1), $\alpha$-quartz transforms to $\beta$ quartz at $573{ }^{\circ} \mathrm{C}$. Since $\alpha$-quartz is rhombohedral and the $\beta$-quartz is hexagonal, the transformation is accompanied by a volume increase of approximately $4 \%$ [17], which can lead to the destruction of the aggregate particles (Figs. 5a and 6a).

The brownish particles are thought to represent the area of concrete that was the closest to the impact. In terms of the phase change as a function of temperature, similar conclusions can be drawn for the brownish materials and for those drawn from the powder collected near the impact zone. In addition, three new phases were observed (Table $2 \mathrm{~b}$ ): $\mathrm{Ca}_{54} \mathrm{MgAl}_{2} \mathrm{Si}_{16} \mathrm{O}_{90}$, an unnamed calcium magnesium aluminum silicate; periclase $\mathrm{MgO}$; and a form of wollastonite with $\mathrm{Mg}$ and Fe substitutions, $\mathrm{Ca}_{0.949} \mathrm{Mg}_{0.010} \mathrm{Fe}_{0.036-}$ $\mathrm{SiO}_{3}$. The nature of the brownish material remains unclear at this stage but will be further investigated in the future.

The microstructural evolution during impact and penetration testing was a series of complex processes involving phase changes, dehydroxylation, gas evaporation, and the formation of new phases. A possible approach to improving the impact resistance of UHPC materials is to replace quartz with other types of aggregates that would not undergo crystalline transformation in the temperature range the material experiences during impact. Some research teams have used silico-calcareous aggregate, crushed limestone, calcined bauxite, and even fly ash and ground granulated blast furnace slag to avoid this problem $[8,14,19]$.

Another approach would be to include volatile species in the concrete that can easily evaporate with increasing temperature and thus create a network of escape routes for the gas phases, such as water vapor and $\mathrm{CO}_{2}$, evolved during impact. A potential material for this purpose is polypropylene fibers $[20,21]$, which melt at a relatively low temperature compared with the decomposition temperatures of the cement phases. It is important to note that the relatively low melting rates of polymer fibers with respect to the rapid heating rate induced by projectile impact should be considered when designing such composites. The effectiveness of this approach will be explored in future studies.

\section{Conclusions}

This study investigated the effects of projectile impact and penetration on microstructure and the phase changes in two UHPCs. Based on microstructural examination, both materials exhibited 
excellent bonding between the quartz particles and the cement paste in the untested state, although the Ductal ${ }^{\circledR}$ concrete exhibited a better adherence to its reinforcement fiber than did the ERDC-M. Compared with conventional concretes, these two materials had a higher amount of anhydrous clinkers embedded in a dense and compact $\mathrm{C}-\mathrm{S}-\mathrm{H}$ phase.

After impact testing, many small particles were observed on the fracture surfaces of both ERDC-M and Ductal ${ }^{\circledR}$ samples, probably fractured pieces of silica formed during the impact testing. The large stress induced by the impact could explain the fracture of quartz grains. In addition, the phase transformation of $\alpha$-quartz to $\beta$-quartz at $573{ }^{\circ} \mathrm{C}$ as a result of temperature increase could also generate internal stresses that help to break quartz grains.

Evidence of various phase changes due to impact and penetration was detected by XRD. Compared with the control sample, the tested UHPC exhibited the possible presence of coesite, a high-pressure, high-temperature form of silica. Other possible phase changes during impact could include transformations from belite to larnite and from tobermorite to clinotobermorite, dehydroxylation of portlandite and ettringite, and formation of new phases such as calcite and spinel.

For future work, in situ microstructure characterization will be performed on these novel UHPC materials. For example, high-temperature X-ray diffraction and a scanning electron microscope equipped with a heating stage will be used to study the effect of temperature on the phase and microstructure evolution, respectively.

\section{Acknowledgment}

This research was carried out at Oak Ridge National Laboratory under contract DE-AC05-000R22725 with UT-Battelle, LLC. This work was sponsored by the Department of Homeland Security, Science and Technology Directorate, Infrastructure Protection and Disaster Management Division: Dr. John Fortune and Ms. Mila Kennett, Program Managers. The authors wish to extend our appreciation to the Concrete and Materials Branch - ERDC personnel for their diligent efforts in specimen preparation and quasi-static, unconfined compression testing and to Drs. William D. Reinhart and Tom F. Thornhill at the Sandia National Laboratories for the impact and penetration tested specimen panels. Permission to publish was granted by the Director, Geotechnical and Structures Laboratory, ERDC. Approved for public release; distribution is unlimited.

\section{References}

[1] Bindiganavile V, Banthia N, Aarup B. Impact response of ultra-high-strength fiber-reinforced cement composite. ACI Mater J 2002;99(6):543-8.

[2] Wu C, Oehlers DJ, Rebentrost M, Leach J, Whittaker AS. Blast testing of ultrahigh performance fibre and FRP-retrofitted concrete slabs. Eng Struct 2009;31(9):2060-9.

[3] Cwirzen A, Penttala V, Vornanen C. Reactive powder based concretes: Mechanical properties, durability and hybrid use with OPC. Cem Concr Res 2008;38(10):1217-26.

[4] Yazici H, Yardimci MY, Aydin S, Karabulut AS. Mechanical properties of reactive powder concrete containing mineral admixtures under different curing regimes. Constr Build Mater 2009;23(3):1223-31.

[5] Weber S, Rümmelin A. Ultra high performance fibre reinforced cement composite under dynamic loading. In: Grosse CU, editor. Adv Constr Mater. Berlin: Springer; 2007. p. 229-35.

[6] De Larrard F, Sedran T. Optimization of ultra-high-performance concrete by the use of a packing model. Cem Concr Res 1994;24(6):997-1009.

[7] Richard P, Cheyrezy M. Composition of reactive powder concretes. Cem Concr Res 1995;25(7):1501-11.

[8] Yazici H. The effect of curing conditions on compressive strength of ultra high strength concrete with high volume mineral admixtures. Build Environ 2007;42(5):2083-9.

[9] Lehmann C, Fontana P, Muller U. Evolution of phases and micro structure in hydrothermally cured Ultra-High Performance Concrete (UHPC). In: Proceedings of Nanotechnology in Construction 3; 2009. p. 287-93.

[10] Habel K, Gauvreau P. Response of ultra-high performance fiber reinforced concrete (UHPFRC) to impact and static loading. Cem Concr Compos 2008;30(10):938-46.

[11] Garas VY, Kahn LF, Kurtis KE. Short-term tensile creep and shrinkage of ultrahigh performance concrete. Cem Concr Compos 2009;31(3):147-52.

[12] Tai YS. Flat ended projectile penetrating ultra-high strength concrete plate target. Theoretic Appl Fract Mech 2009;51:117-28.

[13] Zhang MH, Shim VPW, Lu G, Chew CW. Resistance of high-strength concrete to projectile impact. Int J Impact Eng 2005;31(7):825-41.

[14] Zhou XQ, Kuznetsov VA, Hao H, Waschl J. Numerical prediction of concrete slab response to blast loading. Int J Impact Eng 2008;35(10):1186-200.

[15] DiPaolo BP, Green BH, Boone RN, Magee RE. An investigation of UHPC/RPC materials for enhanced penetration resistance. US Army Engineer Research and Development Center Report ERDC/GSL TN-10-1; 2010.

[16] Thornhill TF, Reinhart WD. Ballistic penetration test results for Ductal ${ }^{\circledR}$ and ultra-high performance concrete samples. Sandia Report SAND2010-2222. Sandia National Laboratory, March 2012.

[17] Barsoum MW. Fundamentals of ceramics. New York: McGraw-Hill Co., Inc.; 1997.

[18] Kingery WD, Brwen HK, Uhlmann DR. Introduction to ceramics. 2nd ed. New York: Wiley-Interscience; 1976.

[19] Yazici H, Yigiter H, Karabulut AS, Baradan B. Utilization of fly ash and ground granulated blast furnace slag as an alternative silica source in reactive powder concrete. Fuel 2008;87:2401-7.

[20] Aydin S, Yazici H, Baradan B. High temperature resistance of normal strength and autoclaved high strength mortars incorporated polypropylene and steel fibers. Constr Build Mater 2008;22(4):504-12.

[21] Kalifa P, Chene G, Galle C. High-temperature behaviour of HPC with polypropylene fibres - From spalling to microstructure. Cem Concr Res 2001;31(10):1487-99.

[22] Neeley BD, Walley DM. VHS concrete. Mil Eng 1995;572:36-7.

[23] Cheyrezy M. Structural applications of RPC. Concrete 1999;33:20-3. 